\title{
SEASONAL DIVERSITY OF BIRDS IN NAGARJUN FOREST OF SHIVAPURI NAGARJUN NATIONAL PARK, KATHMANDU, NEPAL
}

\author{
Praveen Kumar Jha \\ Lecturer, Department of Zoology, Tri-Chandra M. Campus, Tribhuvan University, \\ Kathmandu, $T U$ \\ Corresponding author: jhapraveenkumar8@gmail.com
}

\begin{abstract}
Nagarjun forest of Shivapuri Nagarjun National Park plays a significant role in the conservation of avifaunal diversity, but there are very few studies on birds of such local biodiversity hotspots in Nepal. The objective of the present study was to obtain information on seasonal diversity, species richness and relative abundance of birds in Nagarjun forest. The study was carried out from August 2019 to June 2020 covering two seasons (autumn and spring). A total of 97 species of birds belonging to 10 orders and 42 families were recorded from three trails. Total 22 Mackinnon's lists were produced resulting 97 bird species recorded from entire field survey. Passeriformes was recorded as the most dominating order represented by 69 species. Mackinnon's listing and direct observation methods were used to survey birds and Shannon-Weiner diversity index was used for data analysis. Relative abundance showed that most of the species were rare $(54 \%)$ followed by uncommon $(20 \%)$, very common $(15 \%)$ and common $(11 \%)$. Shannon-Weiner diversity index showed higher value for spring $(\mathrm{H}=3.895)$ than autumn $(\mathrm{H}=$ $3.807)$ and evenness was also higher in spring $(E=0.899)$ than autumn $(E=0.887)$. The result indicated higher species richness in spring with 76 species than autumn with 73 species. Based on the Shannon-Weiner index, the overall species diversity was highest in the trail III.
\end{abstract}

Keywords: Nagarjun forest - avifauna - diversity - species richness - season.

\section{INTRODUCTION}

There are about 10,000 living species of birds in the world (Paliwal et al. 2019). Birds vary in their diversity, habitats, abundance and distribution throughout the world (Mohammad \& Krishna 2016). Birds 
play an important role in the ecological functioning of an environment; they also indicate the pollution, help in dispersal of seeds, and act as predators on insects (Bibi \& Ali 2013).

Altogether 886 species of birds (BCN \& DNPWC 2018) and $9 \%$ of the world's birds are known to occur in Nepal. Of these recorded species, around 550 species are resident, 62 species are summer migrant, 150 species are winter migrant, and others are passage migrant and vagrant species (Grimmett et al. 2016). Nine species of birds are listed in protected birds according to NPWC Act 1973 and 111 species of birds are enlisted in CITES category (DNPWC 2018). However, according to BirdLife International (2019) 44 species of the total Nepalese birds are listed in IUCN Red List, which is considered as globally threatened. Among these 8 (18.18 $\%)$ are critically endangered, 9 (20.45\%) endangered and 27 (61.36\%) are listed as vulnerable. According to Grimmett et al. (2000) forests and bushes contribute $77 \%$ of Nepalese breeding birds. Many Nepal's resident species (approximately 550 species) among 878 species are seasonal altitudinal migrants, these species breed at a higher elevation in the mountain region and descend to a lower altitude for wintering (Inskipp et al. 2016).

Every year about 150 species of migratory birds come to Nepal to spend winter from northern countries (Jha 2016). Most of winter migratory birds come to Nepal from China, Mongolia, Korea, the Siberian region of Russia and Central Asia (Jha 2016). Similarly, when summer starts in Nepal, summer migratory birds from the south enter the country for the breeding and other species of birds that migrate from the north return to their summer habitats (Bhushal 2013). Many of these migratory birds come from SubSaharan Africa, a journey of more than 5,000 Km. (Baral \& Inskipp 2005; Bhushal 2013).

Shivapuri Nagarjun National Park is the ninth national park in Nepal established in 2002 and has been identified as an Important Bird and Biodiversity Area (IBA) by BirdLife International in 2005 because of its international importance for threatened species (Baral \& Inskipp 2005). Out of 886 bird species, 320 species have been recorded from SNNP (SNNP 2017). Among which about 117 species of birds are of migratory. Nagarjun forest, part of SNNP, is the closest birding area from Kathmandu Valley; 
however, not much research on avifauna has been carried out in this area so far.

A preliminary checklist of this park has already been reported by the office of Shivapuri Nagarjun National Park in 2017 and the present study aims to give further information about seasonal diversity, relative abundance, species richness and distribution of birds in Nagarjun forest of SNNP.

\section{MATERIALS AND METHODS}

\section{Study area}

The Shivapuri National Park with an area of $144 \mathrm{~km}^{2}$ was initially gazette in 2002 (DNPWC 2018). It was renamed as Shivapuri Nagarjun National Park (SNNP) after the addition of Nagarjun forest patch $\left(15 \mathrm{~km}^{2}\right.$.) in 2009 to form the area of a total $159 \mathrm{~km}^{2}$ (SNNP 2017). Geographically, Shivapuri forest located within $27^{\circ} 45^{\prime}$ to $27^{\circ} 52^{\prime} \mathrm{N}$ latitude and $85^{\circ} 16^{\prime}$ to $85^{\circ} 45^{\prime} \mathrm{E}$ longitude and Nagarjun forest is located within $27^{\circ} 43^{\prime}$ to $27^{\circ} 46^{\prime}$ $\mathrm{N}$ latitude and $85^{\circ} 13^{\prime}$ to $85^{\circ} 18^{\prime} \mathrm{E}$ longitude. The SNNP extends in four districts: Kathmandu, Nuwakot, Dhading, and Sindhupalchowk of Nepal and elevation range from $1350 \mathrm{~m}$ to $2732 \mathrm{~m}$ above mean sea level (DNPWC 2016). The present study was carried out in Nagarjun forest, part of Shivapuri Nagarjun National Park, which covers an area of $15 \mathrm{~km}^{2}$. The study area extends from the base of Nagarjun forest (around 1350 masl) to top of Nagarjun hill (2060 masl). It represents a typical intact of mid-hill forest ecosystem and bears mostly sub-tropical climate and partly temperate climate (SNNP 2010, Chalise et al. 2015). The SNNP comprises four types of forests, viz. (i) Lower mixed hardwood forests, (ii) Chirpine forests, (iii) Oak forests and (iv) Upper mixed hardwood forests, which support rich floral and faunal diversity with several protected, threatened and endemic wildlife species (SNNP 2017). The SNNP harbors 1402 species of plants, of which 1114 species of flowering plants, 282 species of non-flowering plants, gymnosperm, pteridophytes, and fungi (SNNP 2017). SNNP is home to one-third species of orchids of Nepal (123 species). Faunal diversity of park includes 102 species of butterflies, 122 species of insects, 318 species of birds, and 30 species of mammals including nine threatened species (DNPWC 2018). The location map has been shown in Figure 1. 


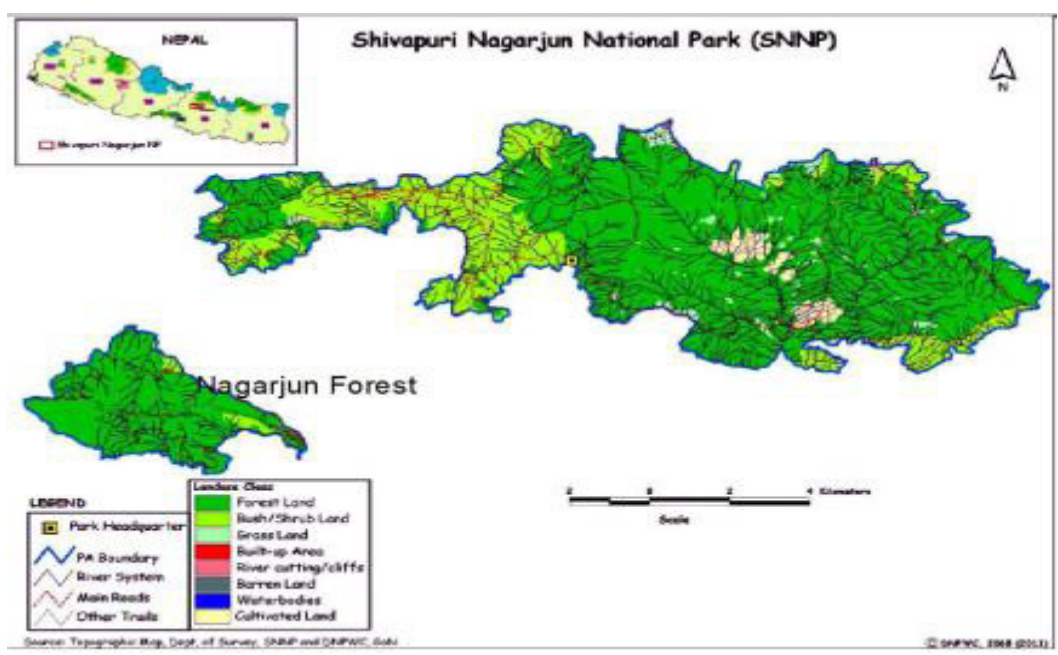

Figure 1: Map showing location of study sites in Shivapuri Nagarjun National Park

The temperature of SNNP varies from $2-17^{\circ} \mathrm{C}\left(36-63^{\circ} \mathrm{F}\right)$ during the winter season and $19-30^{\circ} \mathrm{C}\left(66-86^{\circ} \mathrm{F}\right)$ during the summer season. The annual precipitation of about $1,400 \mathrm{~mm}$ (55 in) falls mostly from May to September, with $80 \%$ during monsoon season (Department of Hydrology and Meteorology 2019, Government of Nepal).

\section{METHODS}

The study was carried out between August 2019 and June 2020 covering two different seasons. Two visits (autumn and spring) were made to three trails (trail "I" run on the outer edge of forest, trail "II" through the altitudinally gradient forest and trail "III" run through the interior forest) of Nagarjun forest. One day was given to each trail during each visit. Birds were mostly observed during the active hours of the morning times $(7.00$ a.m. to 10.00 a.m.) and evening times (15.00 p.m. to 17.00 p.m.). The Mackinnon's species richness counting method (Mackinnon \& Philips 1993) was used as described by Bibby et al. (2000) to estimate species richness in Nagarjun forest of SNNP. MacKinnon's list data from each survey was also used to analyse the relative abundance of a species.

Relative abundance $=$ Frequency of occurrence in lists

The species was categorized as very common (VC) - sighted more than 10 times, common (C) - sighted 7-9 times, uncommon (UC) - sighted 3-6 times, and rare $(\mathrm{R})$ - sighted once or twice. Direct counting of each 
species was used as a secondary method during the bird survey. Names of all species (seen and heard) with the number of individuals were recorded throughout the survey.

\section{Bird species diversity and evenness}

Shannon-Weiner diversity index (Shannon \& Weaver 1949) was used to calculate seasonal bird diversity and species evenness.

Shannon-Weiner diversity index ' $\mathrm{H}$ ' was calculated using the formula:

$$
\mathrm{H}=\quad-\sum(\mathrm{Pi} * \ln \mathrm{Pi})
$$

and Evenness (E) was calculated using the formula:

$$
\mathrm{E}=(\mathrm{H} / \mathrm{Hmax})
$$

Birds were observed with the help of 10x 42 Bushnell waterproof binocular and photographs /videos were recorded by using a Canon Digital SLR camera. A field guide "Birds of Nepal" (Grimmett et al. 2016) and Birds of the Indian subcontinent (Grimmett et al. 2011) were used to identify and name the recorded species.

\section{RESULTS}

\section{Bird diversity}

A total of 953 individuals of 97 bird species belonging to 10 orders and 42 families were recorded from three trails during six days of survey work covering two seasons. A total of 22 Mackinnon's lists were prepared in the recording of 97 species (Figire 2).

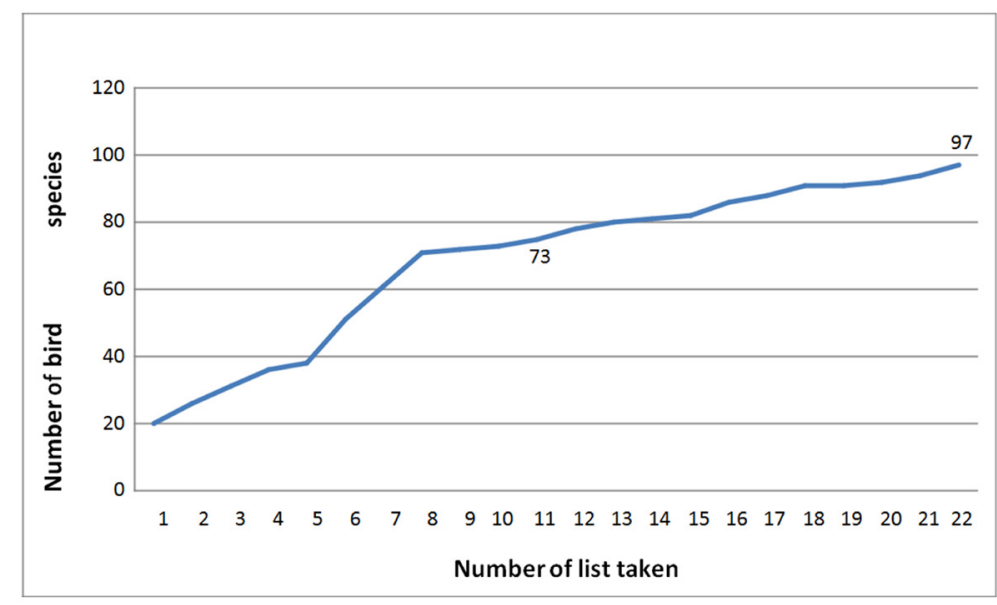

Figure 2: Species richness curve 
A total of 73 bird species was recorded during the first visit (autumn season) and 24 species were added from the second visit (spring season).

\section{Seasonal bird species richness}

Species richness curve resulted from Mackinnon's list shows that the highest number of birds species was recorded from spring season with 76 species in comparison to the autumn season with 73 species (Figure 3 ). 10 lists were prepared from the autumn visit and 12 lists were prepared from spring visit.

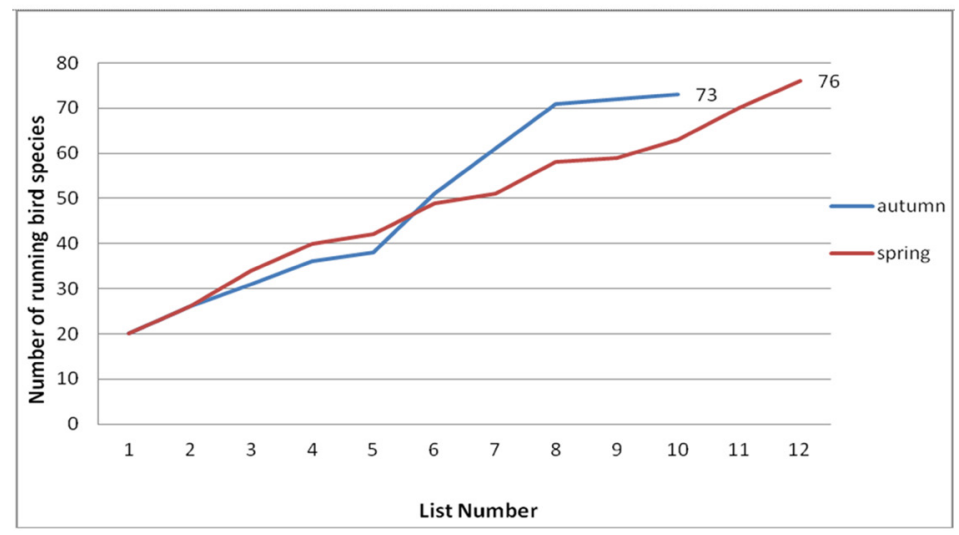

Figure 3: Comparative species richness curve

\section{Species richness along three trails}

Trail III ( 86 species) was found to be more rich in species than trail II (41 species) and trail I (43 species) (Figure 4).

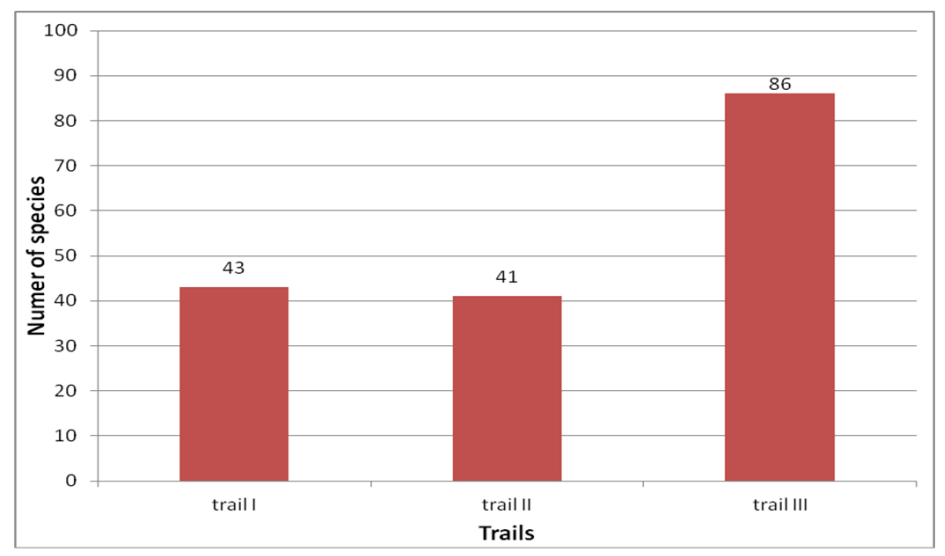

Figure 4: Species richness along three trails 


\section{Relative abundance}

Based on Mackinnon's list produced from the bird survey in Nagarjun forest, $15 \%$ (15 species) of birds were very common, 11\% (11 species) common, 20\% (19 species) uncommon and 54\% (52 species) were rare (Figure 5).

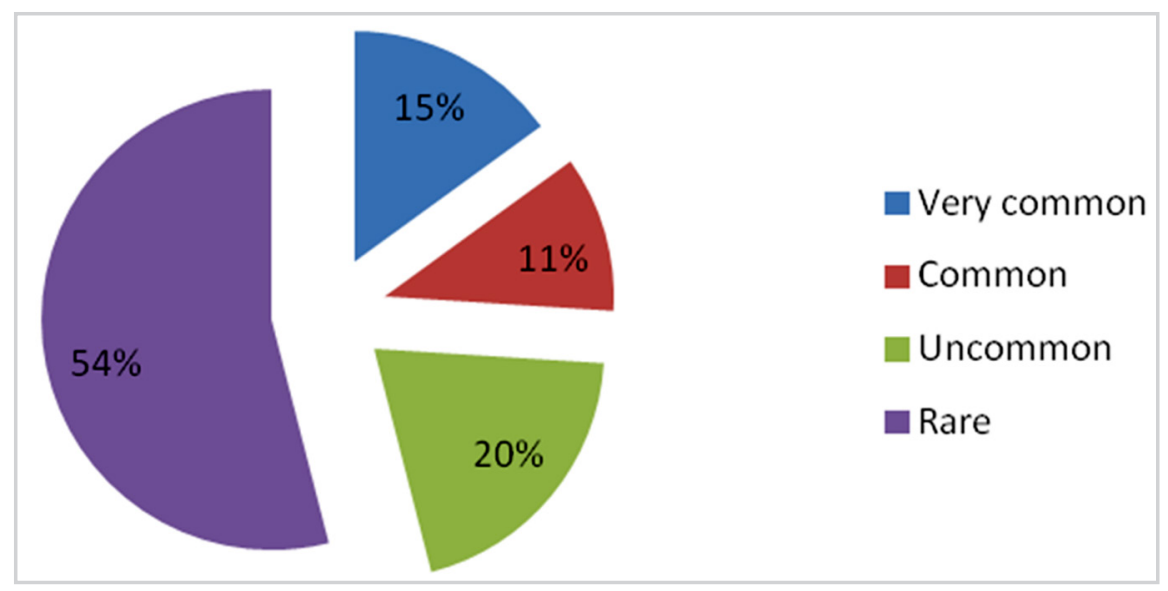

Figure 5: Relative abundance of the birds of the study area

The commonest species was Great Barbet (Psilopogon virens). This was found to be most abundant bird, followed by Black Kite ( Milvus migrans), Red-vented Bulbul (Pycnonotus cafer), Grey Treepie (Dendrocitta formosae), Red-billed blue Magpie (Urocissa erythroryncha). These were recorded in both seasons with high relative abundance and number. Bonelli's Eagle (Aquila fasciata), Spotted Forktail (Enicurus maculatus), Spiny Babbler (Turdoides nipalensis) were some of the rare birds observed only once during the entire survey.

\section{Diversity of birds for two seasons}

Shannon-Weiner diversity index was used to calculate seasonal bird diversity, bird diversity in three different trails and species evenness.

Shannon's diversity index indicate that the spring season had higher species diversity $\left(\mathrm{H}^{\prime}=3.895\right)$ than the autumn season $\left(\mathrm{H}^{\prime}=3.807\right)$. Likewise, the value of E' is higher (0.899) in the spring season in comparison to the autumn season (0.887), hence bird species are evenly distributed in spring. 
Table 1: Shannon-weiner diversity index for two seasons

\begin{tabular}{lllcccccc}
\hline Season & $\mathbf{S}$ & $\mathbf{N}$ & $\sum \mathbf{p i}(\mathbf{n} / \mathbf{N})$ & $\sum \operatorname{lnpi}$ & $\sum[\mathbf{p i} \boldsymbol{i} \ln (\mathbf{p i})]$ & $\mathbf{H}$ & $\mathbf{H}_{\max }$ & Evenness \\
\hline Autumn & 73 & 497 & 1 & -354.7 & -3.807 & 3.807 & 4.290 & 0.887 \\
Spring & 76 & 456 & 1 & -367.3 & -3.895 & 3.895 & 4.330 & 0.899 \\
\hline
\end{tabular}

Source: Field survey, 2019/20

\section{Diversity of birds in three trails}

The value of H' is highest (4.004) in the third trail, hence it is more diverse. Also, the value of E' is highest (0.987) in trail III; hence, in trail III species are evenly distributed.

Table 2: Shannon-weiner diversity index for three trails

\begin{tabular}{cllccrrrr}
\hline Trails & S & N & $\sum$ pi(n/N) & \multicolumn{2}{c}{$\sum \ln \mathbf{n i} \sum[\mathbf{p i *} \ln (\mathbf{p i})$} & $\mathbf{H}$ & $\mathbf{H}_{\max }$ & Evenness \\
\hline I & 43 & 239 & 1 & -181.0 & -3.344 & 3.3443 .761 & 0.889 \\
II & 41 & 167 & 1 & -163.1 & -3.474 & 3.4743 .713 & 0.935 \\
III & 86 & 547 & 1 & -426.7 & -4.004 & 4.0044 .454 & 0.987 \\
\hline
\end{tabular}

Source: Field survey, 2019/20

\section{DISCUSSION}

A total of 97 bird species belonging to 10 orders and 42 families were recorded from two different seasons. The highest number of bird species i.e. 69 were represented by order Passeriformes along with 30 families. The number of bird species in my study seems low when compared to the record of 318 found in Shivapuri Nagarjun National Park (BCN \& DNPWC 2018) which could be limited to study area and covering two seasons of autumn and spring only. Although the survey was carried out within a short period time the observation and data collected from SNNP, reveals that the study area supports a healthy avian diversity. The high bird species richness evinces uniquiness and exquisiteness of the study area. Four species, Greyheaded Woodpecker (Picus canus), Streak throated Woodpecker (Picus xanthopygaeus), Yellow Wagtail (Motacilla flava) and Greater racket tailed Drongo (Dicrurus paradiseus) were new to SNNP which were not previously recorded. From this study, a little difference is seen in species richness during autumn and spring seasons, 73 bird species were recorded in autumn season and no less than 76 bird species were recorded in spring season. Interestingly, the bird diversity was found low in autumn season in comparison to spring season which is probably due to their survivability depending upon availability of plant seeds and insects like ants, termites etc. The transition of weather condition occurs from hot to extreme cold, so at that time plants as well as insects undergoes deterioration, making less availability of foods for 
birds and changing weather condition are also the major factor to decrease bird population in autumn season. During spring season, both late winter and early summer migratory birds were also recorded due to blooming of flowers and exuberant of fruiting trees, which assures food availability. On the basis of recorded facts, this study revealed that birds species were recorded slightly higher in spring season in compare to autumn season.

The highest species richness was found in trail III, which was $1 / 2$ through the interior and $1 / 2$ through buffer zone with 86 species, followed by trail I (43 species) which was through the edge of the forest. Trail II showed a minimum number of bird species (41 species) which was through altitudinal gradient forest. The present research work revealed that Nagarjun forest of SNNP harbors a good number of bird species. This is the first report on the avifauna of this particular area of SNNP. Furthermore, more field-based scientific research work is necessary to prepare a lucid picture about avifauna for the area. In order to identify the total number of bird species in the Nagarjun forest, survey and monitoring of birds is needed in every season.

\section{CONCLUSION}

Altogether 97 bird species belonging to 10 orders and 42 families were observed. This figure indicates that the Nagarjun forest, part of Shivapuri Nagarjun National Park, is the potential habitat for the birds. The avifauna of the study area was rich with both resident as well as migtatory birds.

\section{ACKNOWLEDGMENTS}

I would like to thank IDEA WILD wholeheartedly for giving me research appliances for this project. I am also thankful to Mr. Sabin K.C. and Mr. Nirajan Thapa for their valuable comments and suggestions.

\section{REFERENCES}

Baral, H.S. \& Inskipp, C. (2005). Important bird areas in Nepal: Key sites for conservation. Bird Conservation Nepal and BirdLife International, Kathmandu and Cambridge.

BCN \& DNPWC (2018). Birds of Nepal: An official checklist. Department of National Parks and Wildlife Conservation, Kathmandu, Nepal, pp. 36.

Bhushal, K. (2013). Migratory birds of Nepal and challenges in their conservation. Munal, 1-2. 
Bibi, F. \& Ali, Z. (2013).Measurement of diversity indices of avian communities at Taunsa Barrage Wildlife Sanctuary, Pakistan. Journal of Animal and Plant Sciences, 23(2): 469-474.

Bibby, C., Jones, M. \& Marsden, S. (2000). Expedition field techniques: Bird surveys, BirdLife International.

BirdLife International. (2019). IUCN RedList for birds. http://www.Bird Life.org

Chalise, M.K., Bhattarai, G.P. \& Pandey, P. (2015). Ecology and behavior of assamese monkeys in Shivapuri Nagarjun National Park, Nepal. Journal of Natural History Museum, 27: 12-24. https://doi. org/10.3126/jnhm.v27i0.14149

DNPWC. (2016). Shivapuri Nagarjun National Park (Brochure), DNPWC/ Shivapuri Nagarjun National Park, Panimuhan, Kathmandu, Nepal. Website: www.snnp.gov.np

DNPWC. (2018). CITES listed endangered flora and fauna of Nepal, Department of National Parks and Wildlife Conservation, Babarmahal, Kathmandu, Nepal, pp. 62.

Grimmett, R., Inskipp, C., Inskipp, T. \& Baral, H.S. (2000). Birds of Nepal. Helm Field Guide. Prakash Books. New Delhi.

Grimmett, R., Inskipp, C. \& Inskipp, T. (2011). Birds of Indian subcontinent. Helm Field Guide, Oxford University Press, India.

Grimmett, R., Inskipp, C., Inskipp, T. \& Baral, H.S. (2016). Birds of Nepal: a field guide, Second edition. Christopher Helm, London, UK.

Inskipp, C., Baral, H.S., Phuyal, S., Bhatt, T.R., Khatiwada, M., Inskipp, T., et al. (2016). The status of Nepal's Birds: The national red list series. Zoological Society of London, UK.

Jha, P.K. (2016). Status of migratory birds in Nepal. The Journal of University Grants Commission, 5(1): 67-77.

MacKinnon, S. \& Phillipps, K. (1993). A field guide to the birds of Borneo, Sumatra, Java and Bali. Oxford University Press, Oxford p. 491.

Mohammad, M.J . \& Krishna, P.V. (2016). Avifaunal diversity of wyra and paler reservoirs of Khammam District, Telangana, India. Species, An International Journal, 17(57): 160-174. www.discoveryjournals. com

Paliwal, S., Sharief, A., Sidhu, A.K. \& Kubendran, T. (2019). Abundance of avifauna in Bandli Wildlife Sanctuary, Mandi (Himachal Prdesh). 
LS - An International Journal of Life Sciences, 8(1): 11-18. ( DOI : 10.5958/2319-1198.2019.00002.2)

Shannon, C.E. \& Weaver, W. (1949). The mathematical theory of communication. University of Illinois Press, Urbana, Illinois, pp. 144.

SNNP. (2010). Shivapuri Nagarjun National Park, Brochure. Kathmandu: Shivapuri Nagarjun National Park, Panimuhan, Budhanilkantha, Kathmandu, Nepal. www.snnp.gov.np

SNNP. (2017). Shivapuri Nagarjun National Park and buffer zone management plan Fiscal Year 074/075-078/079 (2017/0182021/022), p. 20. 